Acta Biologica Plantarum Agriensis 5(1): 47 (2017) ISSN 2061-6716 (Print), 2063-6725 (Online) http://abpa.ektf.hu/
DOI:10.21406/abpa.2017.5.1.47

$4^{\text {th }}$ CC 2017 Abstract

Poster

\title{
VILMOS PIERS' LICHEN COLLECTION IN THE SAVARIA MUSEUM, SZOMBATHELY
}

Piers Vilmos zuzmógyüjteménye a szombathelyi Savaria Múzeumban

\section{Lajos BALOGH ${ }^{1} \&$ László LŐKÖS ${ }^{2}$}

${ }^{1}$ Savaria Museum, Department of Natural History; H-9700 Szombathely, Kisfaludy Sándor u. 9, Hungary; ${ }^{2}$ Hungarian Natural History Museum, Department of Botany; H-1097 Budapest, Könyves Kálmán körút 40, Hungary; e-mail: balogh.lajos@savariamuseum.hu

Establishing and maintaining a considerable plant herbarium Vilmos Piers (18381920) a famous teacher of natural history in the historical military secondary school in Kőszeg became one of the most productive plant collectors of Vas County. His famous herbarium the so-called "Piers-herbarium" deposited in the Savaria Museum (SAMU; Szombathely, Vas County, Hungary) contains a smaller lichen collection as well. His lichen collection consists of 717 specimens, 427 of them are kept in paper bags, a further 290 specimens are mounted on cardboards prepared for educational purposes. Evaluable locality data are provided for 362 specimens of those in paper bags. 155 of them represent the lichen flora of the region of Kőszeg town at that time, including also some specimens from nearby areas belonging to Austria today. Most of the specimens collected outside the Carpathian Basin are originated from exsiccates. As a result of our revision a total of 210 lichen taxa from 103 genera, furthermore six taxa of microfungi and one liverwort taxon were identified or confirmed. 170 specimens were collected by Piers himself, others were gathered by 24 collectors altogether from 14 countries. Identifications were carried out by the collectors, as well as by Viktor Cypers von Landrecy and Dr Albert Latzel. Specimens indicated by collecting dates were collected between 1875 and 1910, collections by Piers himself date back between 18 July 1889 and 6 November 1909. The lichen collection of Piers represents the most important lichenological data source of the Kőszeg Mts and adjacent areas, several lichen species are known from this region exclusively from Piers' collections (e.g., Anaptychia ciliaris, Cladonia cervicornis, Cladonia cornuta, Enchylium polycarpon, Lathagrium auriforme, Nephroma parile, Peltigera leucophlebia, Tuckermannopsis chlorophylla). A great part of the collection was revised by László Gallé more than 40 years ago, but a detailed enumeration has never been published by him. The most complete catalogue of the lichen collection based on revised specimens was published by us recently in Savaria Bulletin of Museums of County Vas 38 in 2016, Szombathely.

Chemical analyses necessary for species identifications were financed by the grant OTKA K 81232. 